\title{
IMPACT OF INSTRUCTIONAL MATERIALS IN TEACHING AND LEARNING OF BIOLOGY IN SENIOR SECONDARY SCHOOLS IN YAKURR LG A.
}

\author{
EFFIONG, OJI EKPO, IGIRI CHARLES E. \\ DEPARTMENT OF INTEGRATED SCIENCE \\ CROSS RIVER STATE COLLEGE OF EDUCATION \\ AKAMKPA-NIGERIA
}

E-mail address: effioji@yahoo.com

\begin{abstract}
Keywords: instructional materials, percentages, senior secondary II, students, yakurr etc.
\end{abstract}
\begin{abstract}
This study was designed to determine the impact of instructional materials in teaching and learning of Biology by SS II students in Yakurr local government area of Cross River state. In order to effectively handle the study, four research questions were formulated to guide the study. The descriptive statistical method was employed so as to determine the impact of teacher's effectiveness. Five (5) comparable secondary schools were selected to represent the population of the study. The data collected were analyzed using simple percentage method to verify the research questions formulated for this study. The result of the findings revealed that there is a positive achievement in students taught by highly qualified biology teachers and those exposed to instructional materials during lessons. It was recommended that government make available to schools the basic instructional materials as this will enhance an effective teaching and learning process.
\end{abstract}

\section{INTRODUCTION}

Instructional materials are print and non-print items that are rested to impact information to students in the educational process.

Instructional materials include items such as: kits, textbooks, magazines, newspapers, pictures, recording videos etc.

Instructional materials play a very important role in the teaching and learning process. It enhances the memory level of the students. At this time that education has spread wide and entirely, oral teaching cannot be the key to successful pedagogy; therefore the teacher has to use instructional materials to make teaching and learning process interesting (NIC hulls, 2003; Raw 2006) . According to Abdullahhi (2010), instructional materials are tools locally made or imported that help to facilitate the teaching/learning process. Obanga (2005) view them as materials things which are use to composed ported that could make tremendous enhancement of intellectual use impact the instructional materials

The use of instructional materials can enhance the learning achievement. Cronbach (2009) states the important elements of behaviour that provides the base for learning theory situation which consists of all the objects, persons and symbols in the learning environment.

Experience in situation prepares a person to respond to similar situation in future. Use of instructional materials can appeal to the individual attention by creating interest goal that will help the learner achieve direct effort. Teacher's problem of motivation is essentially one of arranging situation with instructional materials in which the learner will see goals he want to attain. Brown etal (2005) summarized the role of teaching aids as follows:

- It promotes meaningful communication and effective learning.

- They ensure better retention, thus making learning more permanent.

- They help to overcome the limited classroom by making the inaccessible accessible.

- They provide a common experience upon which late learning can be developed. They stimulate and motivate students to learn. 
- They encourage participation especially if students are allowed to manipulate materials used.

Osuala (2010) in his own contribution said it does not only help to motivate and develop interest on the part of the student, but also help to bring about an enhance respect for teachers knowledge of the subject. Instructional materials are also described as concrete or both to the sense organs during teaching (Aginna-Obu 2000).

The nature of the learning and the wide range of student's abilities in the average classroom necessitate a high degree of teachers and experience in the method of presenting the subject matter. This has been truncated with the unavailability of instructional materials in schools.

However, a common goal a teacher carries wherever he is, is to make lesson presentation vitally fresh, stimulating and testing for their students. This will help the teacher to individualize the learning method as well as the content and also working according to the student's need. This goal can be reached most effectively through the use of instructional materials

The need to emphasis on the use and importance of instructional materials in any learning and teaching environment cannot be underestimated. For any learning to take place, the teacher has to make use of these materials that would enable him to teach effectively.

Equipment and other instructional materials to the some extent determine the method the teacher uses in teaching biology. The method adopted could be demonstration, experimental, discussion etc.

It is generally agreed by both teachers and school administrator that apart from the chalkboard and textbooks which are often available for the teacher to use, there are other materials that aid or are capable of complementing the teacher's effort in teaching/learning process. Those materials are commonly called "instructional materials".

One of the reasons why students in our secondary schools sometime find it difficult to comprehend immediately what is being taught by the teacher is the non availability of instructional materials that can easily convey the message of the lesson to the learners.

Orji (2000) asserts that teaching aid is "the guidance of learning activities" that "a teacher uses to motivate and arouse student's desire to learn"

From the fore-going statement, it can be agreed that for effective learning to take place, a student need to be properly guided by the teacher by way of employing various method and means through which his teaching could be meaningful.

\section{STATEMENT OF THE PROBLEM}

In spite of the importance of instructional materials to academic performance of students, it is observed that most students complain of being taught principles that seem to be abstract in nature.

It is on the strength of the above, that the researcher deems it necessary to research so as to highlight the role that instructional materials play in teaching and learning process and also study the problems that are associated with effective application of instructional materials in teaching and learning of biology in senior secondary schools in Yakurr.

\section{Research questions}

This research will answer the following questions:

- Do instructional materials influence student academic achievement?

- Can students taught with instructional materials achieve higher score than those taught without the use of teaching aids?

- Can instructional materials foster self-teaching and assessment there by permitting the learner to advance at his own pace and thereby get immediate reward for teaching?

- Do instructional materials promote retention 


\section{METHODOLOGY}

Descriptive research design was adopted for this study. This is preferred because it determines the impact of teacher's effectiveness on academic performance of biology students in secondary schools in Yakurr local government area.

Population of the study

The population of the study consists of all senior secondary schools (SS II) students in Yakurr local government area.

\section{Sample and sampling techniques}

The researcher made use of the sample size of twenty (25) students and five (5) teachers from each of the five (5) comparable and public secondary schools randomly selected for the study.

Pieces of paper were written alphabetically to represent each school. The first five papers were picked representing the five (5) schools to be used as samples, the sample size was considered adequate as this could reduce sampling error and enable generation of result as show in the table below.

Table 1 Number of students and teachers selected from each of the sample schools.

\begin{tabular}{|l|l|l|l|}
\hline S/N & Names of schools & No. of student & Teachers \\
\hline 1. & Community secondary school Ugep & 25 & 5 \\
\hline 2. & Comprehensive school Ekori & 25 & 5 \\
\hline 3. & Community secondary school Mkpani & 25 & 5 \\
\hline 4. & Community secondary school Nko & 25 & 5 \\
\hline 5. & Community secondary school Idomi & 25 & 5 \\
\hline & Total & $\mathbf{1 2 5}$ & $\mathbf{2 5}$ \\
\hline
\end{tabular}

\section{INSTRUMENT FOR DATA COLLECTION}

To carry out this study a self-structured questionnaire was designed to generate information on the basis of the research question. The questionnaire was divided into two sections " $A$ " and "B". Section "A" elicited information in demographic variables such as student's academic performance and location of school. Section "B" consists of (eight) items on the effect of teachers effectiveness on the academic performance of biology students in the five secondary schools selected fro the study. The respondents were required to tick under the alternative of their best choice. The four point Likert (2009) scale ranging from strongly agree (SA) agree (A), disagree (D) and strongly disagree (SD) was adopted. The respondents, responded to the items they like, and the four point scale was eventually summarized to agree (A) and disagree (D).

To ensure the validation of the instrument, the draft instrument was given to experts in test and measurement in Cross River State College of Education Akamkpa. This is to ascertain the face and content validity of the instrument. The criticisms and correction made by the experts were noted and the necessary corrections effected. This made the instrument to be finally accepted as valid.

\section{METHOD OF DATA COLLECTION}

For the administration and collection of the questionnaire the researcher obtain permission from the school head teacher of the selected secondary schools to carry out the study.

The researcher vividly explained the topic and its implication and the reason why they should sincerely respond to the questions contained in the instrument. After the distribution of the questionnaire, the filled questionnaires were immediately collected by the researcher and the research assistants.

\section{Method of data analysis}

The data gathered through the use of questionnaire and records from the selected secondary schools were analyzed through the use of frequencies and percentages (\%). 


\section{PRESENTATION OF RESULTS}

Table 2 The impact of instructional materials in teaching and learning of students in biology

\begin{tabular}{|l|l|l|l|}
\hline Question & Agree & Disagree & Total \\
\hline Instructional materials make learning real and permanent & 70 & 50 & 120 \\
& $(58 \%)$ & $(42 \%)$ & $(100 \%)$ \\
\hline Instructional materials make learning lesson interesting & 80 & 40 & 120 \\
& $(67 \%)$ & $(33 \%)$ & $(100 \%)$ \\
\hline Instructional materials make learning faster & 65 & 55 & 120 \\
& $(54 \%)$ & $(46 \%)$ & $(100 \%)$ \\
\hline Instructional materials promote retention & 74 & 46 & 120 \\
& $(62 \%)$ & $(38 \%)$ & $(100 \%)$ \\
\hline
\end{tabular}

Table one above shows that there is relationship between the use of instructional materials in teaching and learning of student in biology.

This is because $58 \%$ of the respondents agree that instructional materials make learning real and permanent and $67 \%$ indicated that they make lessons interesting.

The presentation also revealed that $54 \%$ of the respondents agree that they make learning faster and $62 \%$ of them of the opinion that instructional materials promote retention.

Table 3 Availability of instructional materials for the teaching of biology in schools.

\begin{tabular}{|l|l|l|l|}
\hline Instructional materials & $\begin{array}{l}\text { Number } \\
\text { available }\end{array}$ & $\begin{array}{l}\text { Number not } \\
\text { available }\end{array}$ & Total \\
\hline Charts & $\begin{array}{l}35 \\
(29 \%)\end{array}$ & $\begin{array}{l}85 \\
(71 \%)\end{array}$ & $\begin{array}{l}120 \\
(100 \%)\end{array}$ \\
\hline Poster & 30 & 90 & 120 \\
& $(25 \%)$ & $(75 \%)$ & $(100 \%$ \\
\hline Maps & 40 & 80 & 120 \\
& $(33 \%)$ & $(67 \%)$ & $(100 \%$ \\
\hline Globes & 30 & 90 & 120 \\
& $(25 \%)$ & $(75 \%)$ & $(100 \%)$ \\
\hline Video tape recorder & 12 & 108 & 120 \\
& $(10 \%)$ & $(90 \%)$ & $(100 \%)$ \\
\hline Cassette tape recorder & 20 & 100 & 120 \\
& $(17 \%)$ & $(83 \%)$ & $(100 \%)$ \\
\hline
\end{tabular}

As it can seen in table above, $29 \%$ of the respondents indicated that they have charts and $25 \%$ agreed that they have posters, while $75 \%$ also said that they do not have globes.

The presentation also revealed that $10 \%$ have video tapes and $17 \%$ said they have cassette tape.

\begin{tabular}{|l|l|l|l|l|}
\hline Item & Always & Never & $\begin{array}{l}\text { Once a } \\
\text { week }\end{array}$ & $\begin{array}{l}\text { Once a } \\
\text { term }\end{array}$ \\
\hline $\begin{array}{l}\text { I use instructional materials in the } \\
\text { classroom }\end{array}$ & $\begin{array}{l}70 \\
58 \%\end{array}$ & $\begin{array}{l}30 \\
25 \%\end{array}$ & $\begin{array}{l}20 \\
17 \%\end{array}$ & \\
\hline
\end{tabular}

Table 4 Factors that affect the use of instructional materials in the classroom

\begin{tabular}{|l|l|l|l|l|l|}
\hline Item & $\begin{array}{l}\text { Poor } \\
\text { remuneration }\end{array}$ & $\begin{array}{l}\text { Poor condition of } \\
\text { service }\end{array}$ & $\begin{array}{l}\text { Low social } \\
\text { status }\end{array}$ & $\begin{array}{l}\text { Teachers } \\
\text { work load }\end{array}$ & Total \\
\hline $\begin{array}{l}\text { Willingness to use } \\
\text { teaching aids is } \\
\text { affected }\end{array}$ & $\begin{array}{l}25 \\
(21 \%)\end{array}$ & $\begin{array}{l}40 \\
(33 \%)\end{array}$ & $\begin{array}{l}15 \\
(13 \%)\end{array}$ & $\begin{array}{l}120 \\
(100 \\
\%)\end{array}$ \\
\hline
\end{tabular}

Table four above show how certain factors can affect the use of instructional materials in the classroom $33 \%$ the respondents indicated that they do not use them because of poor remuneration, $21 \%$ said they do not use them because of poor condition service, $33 \%$ of the teachers also contributed their inability to use them because of low social status and $13 \%$ attributed it to much workload. 


\section{INTERPRETATION AND DISCUSSION OF RESULTS}

The results of findings based on the analysis of data and research questions presented in the preceding section were interpreted and discussed as follows:

\section{Question one}

Is there any significant influence between the uses of instructional materials on the academic performance of students in biology?

The data in table one were said to answer this research question. The result shows that instructional materials promote retention and arouse learner interest.

For example $62 \%$ of the respondents indicated that instructional materials make learning real and permanent.

However, a very significant percentage (38\%) of the respondents arrived that instructional materials do not promote retention. This is somehow contradictory because if instructional materials make learning real and permanent, it invariable means that they will promote retention.

\section{Question two}

What is the availability of instructional materials for teaching of biology? The result as shown in table two revealed that those materials are not sufficient in school. For instances, $58 \%$ said that they do not have charts and $64 \%$ of them attested to the fact that they do not have posters.

However, a very low percentage $(10 \%)$ indicated that they have video tape. This result corroborates the observation of erudite scholars like Ibe-Bassey (1988) who posited that the extent of usage of instructional materials by teachers was not commensurate to availability.

\section{Question three}

Do biology teachers make use of instructional materials in the classroom?

The result as presented in table three revealed that biology teachers make use of instructional materials in the teaching of the subject.

This is confirmed by the fact that $58 \%$ of the teachers reported that they make use of instructional materials always and only $17 \%$ indicated that they made use of them once in a week.

However, $25 \%$ of them indicated that they never make use of instructional materials. The result is in support of the view of Ibe-Bassey (1988). He observed that teachers had these materials such as bulletin boards, Maps and Globes, Posters, drawing and paintings at their disposals.

He therefore called on school heads to continue to supervise their teachers more closely on the use of instructional materials in the classroom. Ogar (1990), also supported the view that media use in instructions as not encouraging.

He stressed further that factor like job satisfaction, teachers professional training also impact teacher's use of instructional materials in instructions.

\section{Question four}

What are the factors that impact teachers in the use of instructional materials in the classroom? The data in table four were use to answer this question. The result shows that the willingness to used instructional materials in the classroom by biology teachers is affected by some factors.

For example, $21 \%$ of respondents indicated that they do not use them because of poor condition of services. In fact, $33 \%$ of the respondents averred that their social status influence the use of instructional materials in the classroom.

The result of analysis showed that use of instructional materials affect the academic performance of students but the instructional materials available for the teaching of the subject in school are grossly inadequate.

The study also revealed that teachers do not effectively make use of the available materials always because of certain factors that affect them 


\section{CONCLUSION}

The findings derived from the study include:

i. The use of instructional materials impact teaching and learning of students in biology

ii. The use of teaching aids make learning real and permanent

iii. Biology teachers do not always make use of available teaching aids during instruction.

iv. Teaching aids available for the teaching of biology is grossly inadequate and this negatively affects effective teaching and learning

v. The use of instructional materials promotes retention

vi. The use of teaching aids influences the academic achievement of students in biology.

Based on these findings it was found that instructional materials play a vital role on student's academic performance in senior secondary two students in biology.

Proper presentation of good instructional materials and the methodology employ by the teacher will enhance good understanding of the subject matter.

\section{RECOMMENDATIONS}

In the light of the conclusion drawn from the analysis and facts presented in the study, the researcher endeavored to make some recommendations. These recommendations were aimed at paving way for Nigerian schools in Cross River State and Yakurr local government area in particular to improve more on creating and uses of instructional materials in all the secondary schools. In doing so it will help the students to carry out their learning activities with a lot interest to ensure their good academic achievement at the end of their senior school examination in biology.

The researcher therefore recommends that:

- The government should provide instructional materials in schools to enable teachers use them in instruction.

- The government should establish resources centers to enable teachers borrow teaching aids which may not be in the schools.

- The government should organize workshops, seminars and conferences for teachers to enable them up-date their knowledge on new developments on the use of instructional materials.

- Teachers should try hands on the production of simple aids so that students can see what they are talking about in the lessons.

- School heads should supervise their teachers more closely to ensure that the available instructional materials are effectively utilized.

- The teachers, like those in the civil services are a distinctive person and a complex organism. He has a variety of needs, wants, and anxieties, motivation personal problem etc. to satisfy in order to perform his duties effectively. Teachers should be given their free benefits like their counterparts in the civil service

- Findings could be made on the variable that enhance students academic performance such as environment, age, textbook, psychological needs, teachers related factors and counseling services in schools.

It is therefore hoped that if the above recommendations are properly carried out, it will help to improve more the performance of students in senior secondary school biology in Yakurr local government area and Cross River State at large. 


\section{References}

[1] Adoyin, J. A. (2010) instruction to educational technology, Johns Lod publisher 1td, Lagos

[2] Agu, I. (2011) the place of instructional materials in curriculum development; "education and development

[3] Ajayi, K. (2010) Job satisfaction among secondary schools teacher in Nigeria; "African Journal of education research" vol. 3. No. $1 / 2$ April

[4] Clark, L. M. (2009) Teaching tools teaching in the secondary school new York: Macmillan publishing co. Inc

[5] Eshiet, L. T (2013) The use of instructional materials in the teaching of science" (ed) in fundamental of education technology Unicross

[6] Ebuwa, S. E. (2010) strees on the use of teaching aids Nigeria observer, June 9, 4

[7] Fafunwa, B. E. (2011) History of education in Nigeria, London, George, Allen and union ltd

[8] Fidelis, A. Onwioduorit (2009) educational research methodology statistic Dorand publisher P. O Box 1350 Uyo Akwa Ibom State, Nigeria

[9] Ibe (2011): "How Nigeria teacher select interactional materials" British Journal of educational technology vol. 19

[10] Liber, T. F. (2010) Aids for teaching and learner London: George Allen Ibanga, E (2012 instructional materials and educational out comes secondary school books Ibadan: Nigeria

[11] Nkem, B. A (2013) counseling and educational technology Calabar: Piaco. Press ltd National policy on education (Rvised 2010) Federal ministry of education, Lagos 